\title{
Finnish Knowledge-Intensive Business Services in China: Market Entry and Position in the Value Chain Sen Bao and Marja Toivonen
}

\author{
"Man is born free and everywhere he is in chains." \\ Jean-Jacques Rousseau (1712-1778) \\ Philosopher, writer, and composer
}

\begin{abstract}
The internationalization of companies offering knowledge-intensive business services (KIBS) plays an important role in the general process of globalization. As the largest emerging market, China is attractive for Western KIBS. This article presents a case study on Finnish KIBS in China. Three companies in "clean tech" engineering, eco-cities design, and $3 \mathrm{D}$ media solutions describe the challenges and promoting factors in entering the Chinese markets. The study also examines the various ways of positioning the firm in the value chain through the roles of an integrator, a concept developer, and a multi-stage actor. Our findings illustrate the new business opportunities provided by China in advanced service sectors focusing on sustainability issues and creative content.
\end{abstract}

\section{Introduction}

Knowledge-intensive business services (KIBS) are expert companies that provide design and consultancy to other companies and organizations. They offer solutions to both technological (e.g., engineering and ICT) and managerial (e.g., legal, financial, and marketing) issues (Miles, 2005). KIBS have composed the most rapidly growing sector in Western countries for more than three decades, and their internationalization has been argued to be one of the most significant contributors to the general process of globalization (Miozzo \& Miles, 2003). KIBS are particularly important actors in the globalized structures of innovation: internationally operating KIBS transfer knowledge between global, national, and regional levels (Howells \& Roberts, 2000).

Recently, KIBS have also aroused attention in emerging markets, particularly in China (Wei \& Wang, 2005). Studies indicate that KIBS play a crucial role in knowledge flows within regional industrial clusters in China (Shyu et al, 2007). The country-wide development of KIBS is still at an early stage, with a limited scale and expansion ability. However, some geographical regions, particularly the Yangtze River Delta and Pearl River Delta areas, show rapid growth of this sector (Qi \& Guan, 2009).
As a huge market, China is also interesting as a target country for internationalizing Western KIBS. Our study focuses on this topic: we have carried out case research among Finnish small and medium-sized enterprises that offer knowledge-intensive business services in China. We focus on two research questions:

1. What kind of a process characterizes the internationalization of Western KIBS when they enter the Chinese markets?

2. How do KIBS position themselves in the respective value chain when they establish their activities in China?

Based on these questions, we map the challenges and promoting factors in the internationalization of Western KIBS in China.

\section{Internationalization of Services}

The three basic ways to operate on the international markets are: foreign direct investments, exports, and presence through third parties. Foreign direct investments have been considered dominant in services due to the need for close contact between the providers and 


\section{Finnish Knowledge-Intensive Business Services in China}

Sen Bao and Marja Toivonen

clients. The presence through third parties also has its benefits: it provides control over the service delivery and quality, and it requires fewer resources than foreign direct investments (Roberts, 1998).

In exports, sending experts to work in another country has been the predominant model but is increasingly replaced today by online activities - in training and consultancy for instance (Javalgi et al., 2004). However, export projects as a specific form of travelling-based internationalization have "survived" the change. They are particularly common in engineering consultancy, in which the same expertise is used in different countries instead of expansion in one country (Léo \& Philippe, 2001).

In the international operations through third parties, collaboration may concern a common brand, common acquisition of clients and contacts, common subcontracting, common R\&D and training, and even partially common ways of working. Also, deeper forms of cooperation, such as strategic alliances, are possible (Tapscott et al., 2000).

The model that is purposeful for an individual firm depends both on the resources and skills of the firm and on the nature of the service. All models require contacts and material resources as well as know-how in international business. Trusted partners are critical in operations through third parties, whereas material resources are emphasized in foreign direct investment. As regards the nature of the service, the most important question is the extent to which the service is commodifiable and the extent to which the knowledge included is codifiable. If the elicitation and interpretation of tacit knowledge plays a central role, the provider should be present in the delivery (Majkgård \& Sharma, 1998).

In the process of internationalization, a long-lasting view was that service firms either follow their clients to foreign markets, or in the case of independent internationalization, apply a cautious, gradual approach. Later studies have shown that service firms may also internationalize rapidly, following the way that high-tech firms adopted in the mid-1990s (Chetty \& Campbell-Hunt, 2004).

The benefit of following the clients is the reduction of risk: there are contacts in the target country and information about the markets is available right from the start. However, new contacts with local actors may develop too slowly, which causes difficulties if the business of the original client diminishes (O'Farrell et al., 1998). In an independent internationalization, the building of credibility speaks for a gradual approach (Contractor et al., 2003). Companies following this path often initiate their international activities at a small scale in those countries that resemble their domestic market.

KIBS compose a service sector that has shown alternative approaches for decades. For instance, European engineering offices have carried out projects in developing countries since the 1960s (Sharma \& Johanson, 1987). It is not rare either that KIBS "skip" some stages in internationalization or take the steps in a different order in different cases (O'Farrell et al., 1998). The advancement of information and communications technology, which has fostered the development of KIBS in general, is also influential here. Versatile internationalization was first found in software KIBS, and nowadays, it is becoming common in all kinds of KIBS that utilize on-line distribution of services (i.e., for recruitment, training etc.).

An interesting alternative is "born globals" - companies that include international operations in the original business plan and internationalize immediately after their establishment. Internationalization may occur simultaneously in many different forms, such as wired exports, subsidiaries, strategic alliances, non-equity networks, and so on. (Toivonen, 2002). Most "born globals" are small companies whose focus is on some niche area where they attract pioneers throughout the world as their clients.

The different internationalization paths may also be mixed. "Born globals" may take their first international steps in countries with a short "psychic distance" (wiki pedia.org/wiki/Psychic_distance), and only after that penetrate rapidly to global markets (Chetty \& CampbellHunt, 2004). Correspondingly, cautious companies often speed up their internationalization when their experience accumulates. In addition, a service company may follow a client to a target market, but develop its own internationalization strategy simultaneously (O'Farrell et al., 1998). It is also important to point out that a strategic stance is needed irrespective of the specific model and path selected. Within strategic considerations, the positioning the firm in the respective value chain is a key issue.

\section{Value Chains and Value-Offering Points}

Value chains cover the full range of activities from a product or service concept through production and delivery to final consumers and to final disposal after the use (Kaplinsky, 2004). A value chain is usually divided 


\section{Finnish Knowledge-Intensive Business Services in China}

Sen Bao and Marja Toivonen

into primary and support activities. Primary activities consist of inbound logistics, operations, outbound logistics, marketing and sales, and services; support activities include the firm's infrastructure, human resource management, technology development, and procurement (Porter, 1985).

The perspective of value chain has been widely used since the 1990s, often hand in hand with the business model approach (Morris et al., 2005). A value chain is considered a tool to disaggregate a business into strategically relevant activities (Brown, 1997). The value logic has been highlighted in this context. A business model is seen to represent the economic logic in delivering the value to customers at a certain cost (Magretta, 2002). It is a representation of a firm's underlying core logic and strategic choices for creating and capturing value (Shafer et al., 2005). Value for customers has been increasingly emphasized as a prerequisite for provider value (Lusch et al., 2010). Correspondingly, challenging the value chain members to improve the value proposition to end customers has gained ground in value chain management.

According to Rappa (2001), a company generates profit by specifying its position in the value chain. Chesbrough and Rosenbloom (2002) point out that the business model defines the value chain structure of the firm: it determines the offerings and complementary assets needed to support the firms' position in the value chain. A more detailed analysis of this position helps to purposefully manage both the demand and the supply chains. Upstream participants constitute an individual firm's supply chain and downstream participants constitute its demand chain (Horvath, 2001). The value-offering point is the place where the demand and supply chains meet, in other words, where the supplier fulfils demand in the customers' demand chain - here, the customer may be either an intermediary or end user (Holmström et al., 2001).

Research into value chain management and value-offering points has been carried out mainly in the context of manufacturing or service sectors near to it (e.g., retailing). However, the approach also applies to KIBS. In the conventional, arm's-length buyer-seller relationship the value-offering point is based on fulfilling orders. An alternative is the situation in which companies are increasingly interested is "offer to planning", which moves the value-offering point to analyzing the demand categories that can be fulfilled with more knowledge-intensive and also more profitable services. (Holmström et al., 2001)
Today, some authors prefer the term "value network" instead of a value chain (e.g. Allee, 2003). Be it a chain or a network, there is consensus about the importance of integrating the various activities included. The role of KIBS as integrators has aroused much interest because these companies possess the necessary knowledge for understanding and coordinating the multi-tiered and distributed "value segments" (Windrum, 2002; Zhou et al., 2005). The ability of KIBS to take this role, despite their often small size, is based on the combination of generic knowledge with practical applications in their clients' specific operational environments. In addition to functioning as integrators of value offerings, KIBS have been suggested to form key nodes and hubs that synchronize several complex resource domains involving highly embedded tacit knowledge (Miles, 2005). An example is provided by KIBS that facilitate the elaboration of open public data into various services. In the areas of transportation and city planning, for instance, this elaboration requires the bridging of many different stakeholder groups.

\section{Context and Methodology}

Three Finnish KIBS form the basis of our study. Each of the companies is technologically oriented, and they offer "clean tech" engineering (Case A), architectural design (Case B), and 3D solutions in digital media (Case C).

Case A was founded in 2001. It is a leading Nordic company providing carbon asset management and other services in the renewable energy markets. It has carried out more than 100 projects linked to a clean development mechanism between Europe and China. Its business in China is currently focused on an energy management contract (EMC) - an area supported by the local government.

Case B was established in 1979. It has performed hundreds of successful projects in urban, landscape, and building design throughout Finland. Sustainability is emphasized in its design projects. In recent years, Case $\mathrm{B}$ has seized a new opportunity that has emerged in China: the local government has increasingly favoured sustainable design solutions and has applied the ecocity concept, among others. Since 2008, Case B has exported several sustainability projects to China, including infrastructure planning, energy and traffic, and carbon control.

Case C is a stereoscopic 3D company founded in 2007. It offers native $3 \mathrm{D}$ production, 2D-to-3D conversion, and 3D display solutions, including 3D holographic pro- 


\section{Finnish Knowledge-Intensive Business Services in China}

Sen Bao and Marja Toivonen

jection and glass-free 3D. Case $\mathrm{C}$ has not yet established business in China, but it has sent experts there to seek local partners and to find out the demand for its offerings.

In order to obtain in-depth knowledge in quite a new topic, we have applied a qualitative research approach. A multiple-case study was conducted to improve the transferability of results. The data were mainly collected through 12 face-to-face interviews with representatives of the top management teams of each case company. Each interview lasted about one and half hours. The interviews were semi-structured based on the research questions and the literature review. Interviewees were given a great deal of freedom to respond the openended questions (Bryman \& Bell, 2011).

Besides the interviews, we participated in three seminars, which were organized in China by the experts in the fields of our case companies. In these seminars, we had an opportunity to discuss the topic with important stakeholders, including (potential) customers, competitors, partners, and industry experts.

During the data analysis and interpretation, we aimed to form a deep understanding of each case. The interview transcripts were categorized into specific themes that were originally guided by the research questions and interview topics, but were modified on the basis of the emerging issues that came out in the interviews and seminar discussions.

\section{Case Results}

Our results show that local partners play a critical role in China, both in market entry and in further development. However, the detailed methods of organizing partner collaboration and gaining benefits from such collaborations varies in our case companies:

- Case A owns a subsidiary in China through a joint venture with a local partner. In addition to close customer contacts, the influential network provided by the partner has motivated Case A to select this deepest form of local presence. The joint venture and the existing network have diminished the risk linked to investments.

- Case B carries out export projects by sending travelling experts to China. It also has a representative office in its local partner's incubation centre. The partner's re- sources complement Case B's own resources in that office: they can be used for free, but there is a profitsharing agreement for the future projects.

- Case $\mathrm{C}$ is preparing to enter the Chinese market. It has relocated an expert to work with a potential partner and to present itself in China. This expert works partially for Case C and partially for the partner, but a common aim is to cooperatively secure and manage projects.

The case companies also show different paths of entry into Chinese markets. However, all of them have internationalized independently - they have not followed their domestic clients. All of them also show a combination of rapid and cautious steps:

- Case A has perceived China as an important market since its founding: local interest in its expert areas environmental protection and energy saving - is growing and is driven by government policy. However, the energy industry in China is very conservative, and therefore Case A entered this market only after a careful exploration of opportunities. Thereafter, it established its business in China quite rapidly. Experience about subsidiaries in Europe supported this initiative, and a crucial step was finding an appropriate venture partner.

- For Case B, China is the only foreign market. Thus, this company exemplifies the approach of starting international activities from a remote area. Case B focuses on the Chinese eco-cities development that is driven by the government's sustainability policy, and its first project was based on success in an eco-city design competition. An interesting point is the interaction between foreign and domestic markets: not all eco-city projects have generated profit, but the brand effect has helped the company to win projects in the domestic markets.

- Case $\mathrm{C}$ is a genuine born-global company operating in a niche area. It is compelled to extend its business beyond the home country due to the very small $3 \mathrm{D}$ market in Finland. It is present in several foreign countries (e.g., Sweden, Russia, and the United Kingdom). Recently, it has made a preliminary analysis concerning the Chinese 3D market. In order to reduce the risk in the early stage, its preferred form of activities in China is exports via the Internet (e.g., 2D to $3 \mathrm{D}$ conversion). 


\section{Finnish Knowledge-Intensive Business Services in China}

Sen Bao and Marja Toivonen

To summarize the factors that seem to promote the success of Western KIBS in China, we highlight the importance of local references. Our cases show that a joint venture subsidiary enables the rapid accumulation of business cases. However, if this option is not available, even a looser network or an individual "spokesperson" may crucially help during a company's first steps in China. A combination of Western and Chinese representatives seems to be the best way to compile human resources. On one hand, Chinese customers often want to see foreigners in the projects when discussing large lines of business. On the other hand, they prefer negotiating with locals for practical issues.

In addition to the challenge of securing a foothold in China, a reasonable pricing strategy turned out to be a challenge to Western KIBS. Finding a price level that is acceptable to local clients and that provides competitive advantage to the KIBS themselves is not easy. A solution that is typical of our case companies was the combination of Western and Chinese workforces. For instance, company B carries out the design of the core concept in the West with Western resources and prices, whereas the preliminary and follow-up work is implemented in China with local resources and local prices. However, this "traditional" solution based on work allocation was not the only option. Case A applied very modern value-based pricing by sharing the profit with clients.

Customer segmentation is essential in China and one central categorization in this regard is based on the ownership of companies. State-owned, privately owned, and foreign companies show different business behaviours, for instance, in customer-relationship management and decision-making practices. There are also differences in the payment risk. Our case companies reported that state-owned enterprises are quite reliable although the payment may be delayed, but privatelyowned enterprises may be risky. One solution (applied by Case C) is to restrict the after-delivery invoicing to premium customers and invoice the other customers beforehand. This practice also relieves the problem that clients do not always complete the payment: the first invoices that cover the costs are usually reimbursed, but the final part that includes the profit is not always accomplished.

\section{Alternative positioning in the value chain}

All case companies have aimed to find an influential position in their respective value chains in China. They illustrate three different ways to achieve this goal through the roles of an integrator, a concept designer, or a multi-stage actor. An integrator coordinates the business of other stakeholders in the value chain. A concept designer, located upstream in the chain, has the capability of offering profitable services by a holistic analysis of the potential demand. A multi-stage actor may have a more or less influential role depending on which parts of the value chain are combined and how.

Case A represents a value chain integrator (Figure 1). Achieving this role is based on the company's profound knowledge about the energy industry and on its long experience in China. Case A combines the technology, material, components, and equipment of the other providers. More specifically, it offers full services to its clients in energy management contract (EMC) projects, which include energy efficiency audits; energy conservation project design, construction, and equipment installation; and energy conservation monitoring.

There are several factors that support the success of Case A in the role it has selected. The first factor is the profit model. The project funding is based on the EMC concept and consists of Case A's own capital and commercial or special purpose loans. Clients pay the costs back during the contract period (e.g., five years) on the basis of the achieved energy savings. This payment also includes profit for Case A. Second, Case A receives subsidies from the Chinese government based on the investment and energy saving results. Third, the supply chain partners whose operations Case A integrates deliver their products (within the EMC) to the clients via Case A. All parties involved in the EMC business benefit from the arrangement.

Case B has positioned itself upstream in the value chain as a concept designer (Figure 2). Its main activity is in the early design of the eco-city projects. A concept designer has the opportunity to heavily influence the project owner's decisions in the early stages of a project. Thus, Case B's activities are an example of "offer to planning" and of the respective value-offering point (Holmström et al., 2001). By carefully analyzing the project owner's needs and desires, Case B can create a concept that includes both sustainable elements and profitable services.

However, in order to follow the Chinese license regulations in the construction projects, Case B needs to work closely with the local design institute. The company's share of design work compared with the local design institute decreases dramatically when the project proceeds from the schematic design to the preliminary design and further to the construction design. However, 


\section{Finnish Knowledge-Intensive Business Services in China}

\section{Sen Bao and Marja Toivonen}

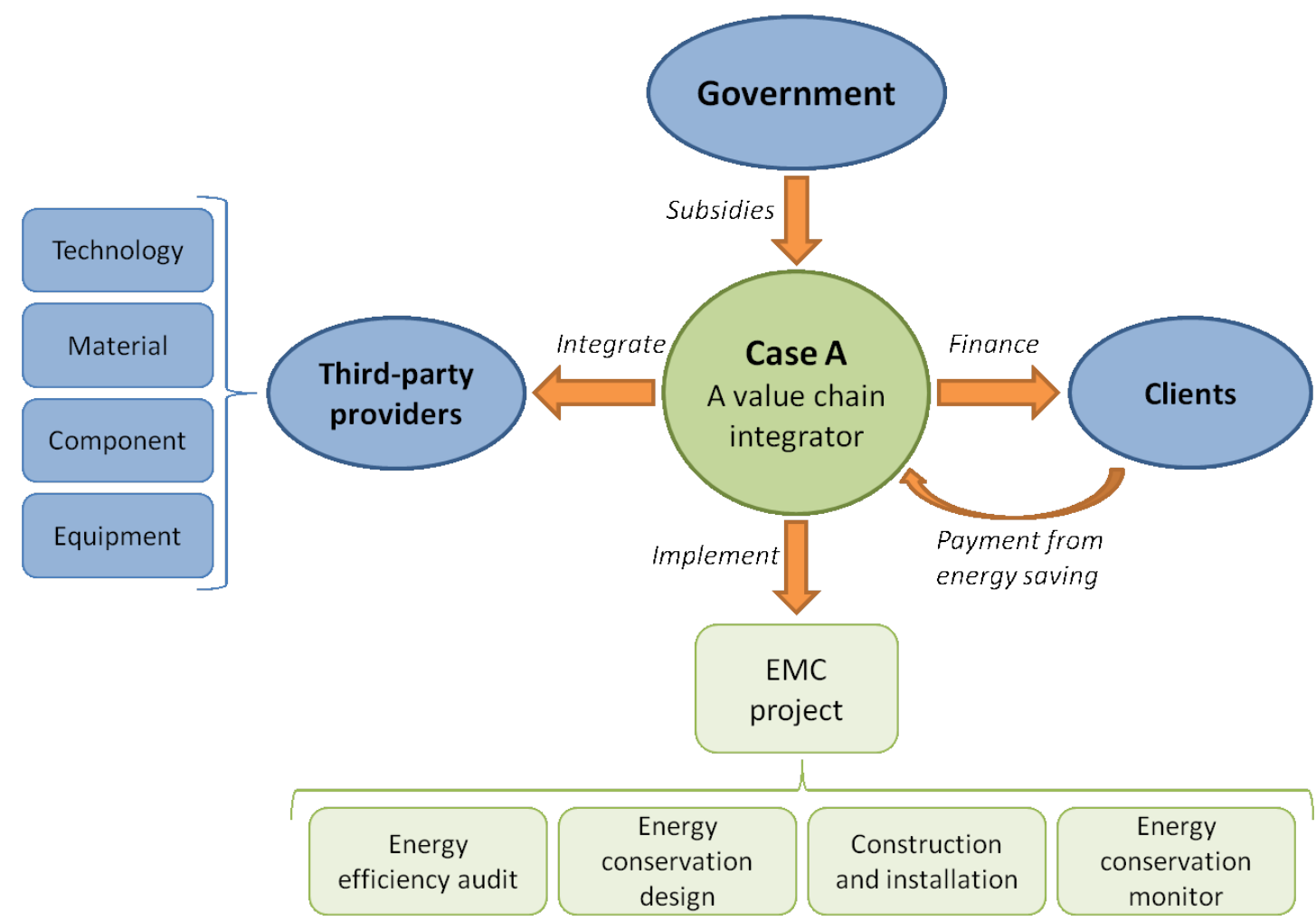

Figure 1. Case $A$ as an integrator in its respective value chain

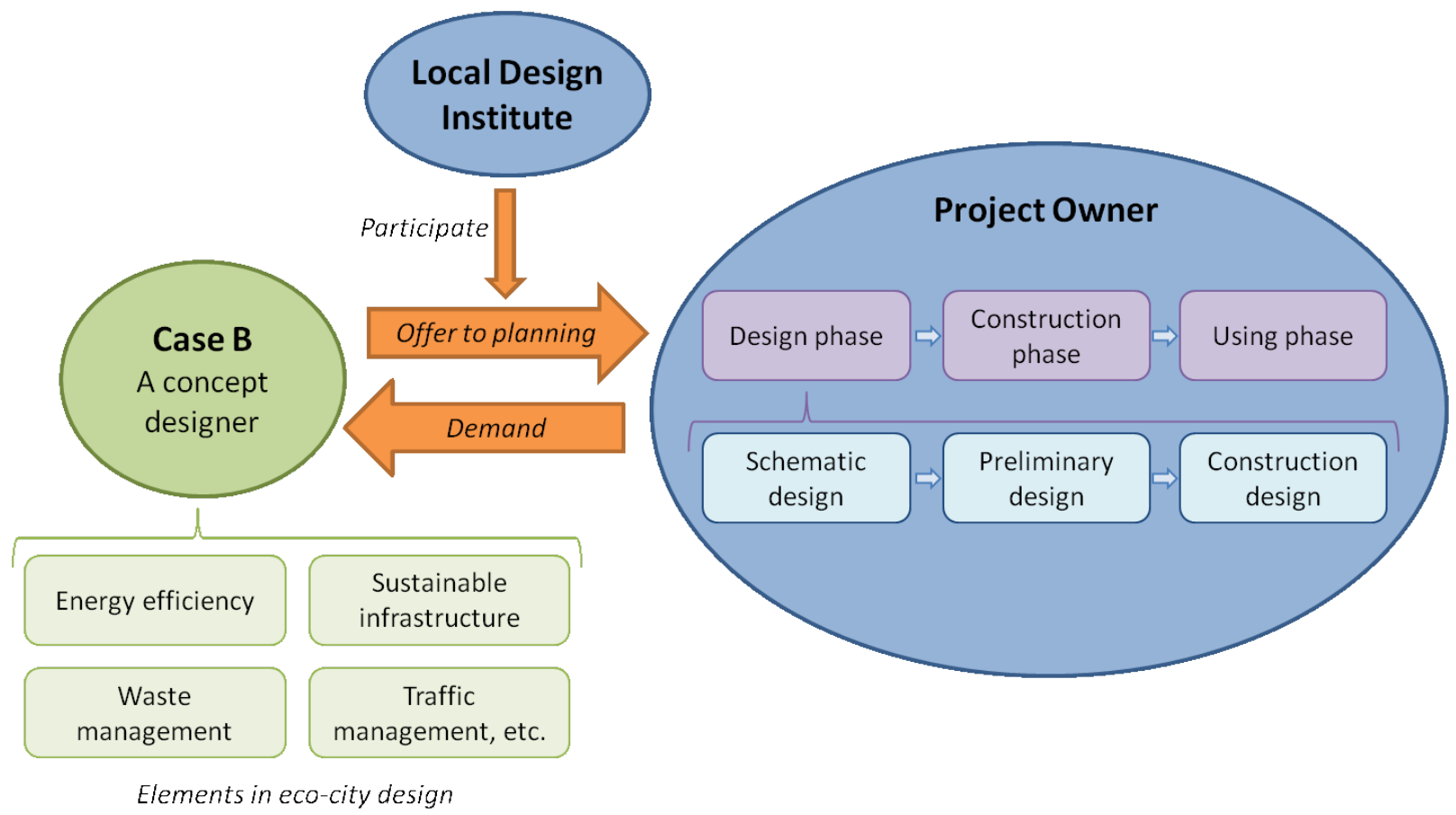

Figure 2. Case B as a concept designer in its respective value chain 


\section{Finnish Knowledge-Intensive Business Services in China}

Sen Bao and Marja Toivonen

its role in consultancy becomes more important and drives the project owner to follow the original concept.

Case C is a multi-stage actor (Figure 3). Its activities focus on two points in the value chain: development and marketing. The company creates $3 \mathrm{D}$ content as a producer, and it resells the content and the related 3D equipment as an agency. In the early stages, just after its founding, the company focused on the former role. The latter role became important in the business practice due to the immaturity of the 3D market: many clients do not have suitable hardware to support the 3D content.

As a newcomer, Case C's activity in China relies on the partners' network. Currently, the company is seeking niche markets to provide $3 \mathrm{D}$ solutions with a premium price. It is also trying to acquire price-sensitive clients and, for that purpose, it aims to reduce costs by using its own technology and its partners' labour resources.

Based on our case observations, we suggest that a KIBS can acquire an influential position in its value chain in many ways. However, there are factors that restrict the possibilities: the length of experience in the domain and in the specific market, the nature of service, among others. Thus, not all alternatives are open to all companies. Analyzing the position in the value chain is, however, always possible and enables the search for an alternative that is influential and achievable.

\section{Conclusion}

This article has examined the ways in which Western KIBS enter Chinese markets and position their business in their respective value chains. Our empirical data consist of a case study including three Finnish KIBS in the areas of clean tech engineering, eco-cities design, and $3 \mathrm{D}$ solutions in digital media. Thus, we have focused on novel issues, not only regarding China as a target country, but also regarding the nature of the expertise offered by the KIBS in relation to sustainability issues and the creative sector.

Our results confirm many earlier findings on the internationalization of services. All basic forms of international operations came out in our study: a subsidiary, export projects, and collaboration with a third party. The form of local presence was linked to the degree of establishment: the company having the longest experience in China had a subsidiary. The company having some experience carried out export projects, and the company taking its first steps operated through a third party. This result confirms the view that companies select more risky forms of foreign operations when their experience grows.

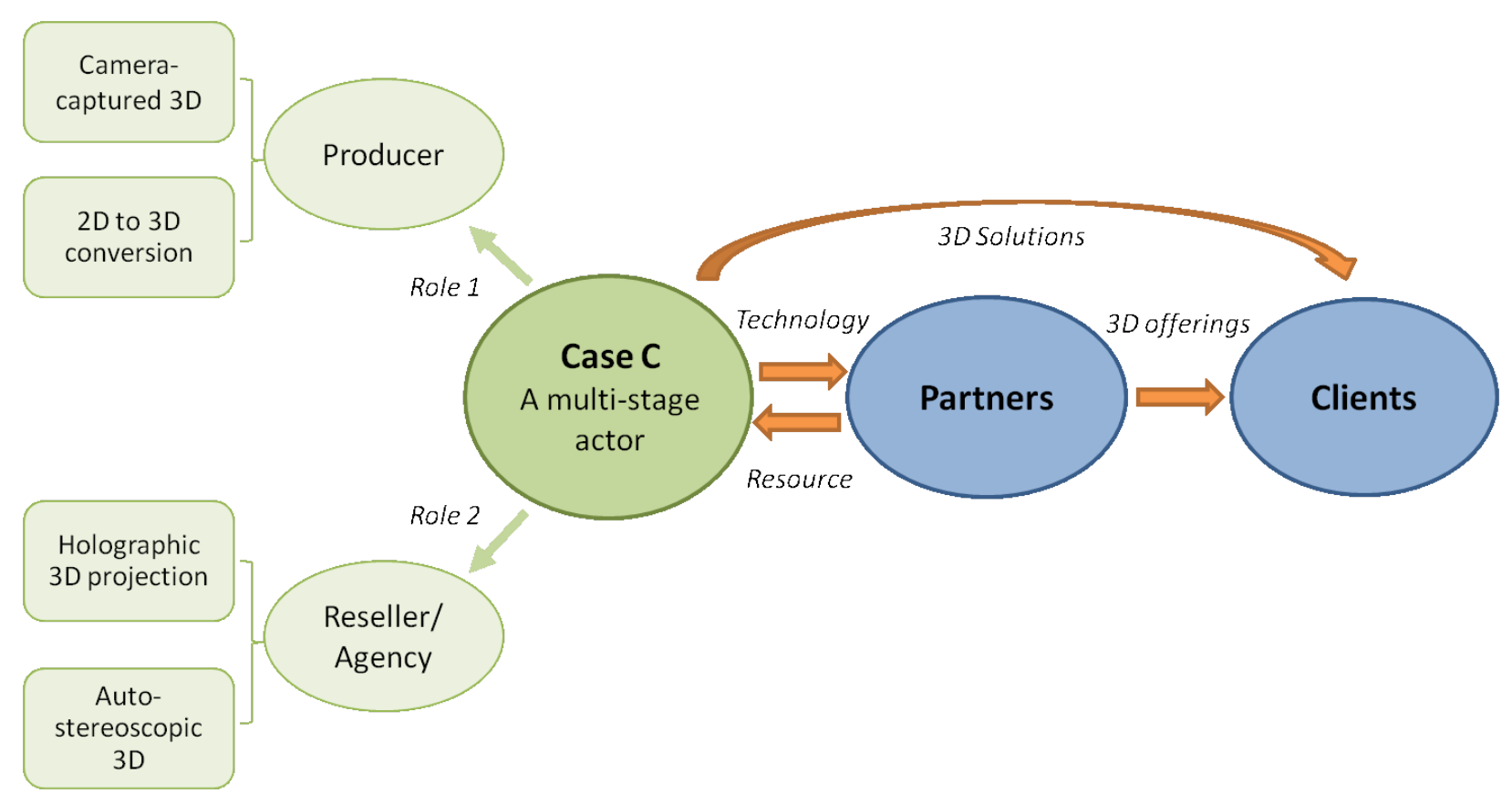

Figure 3. Case $\mathrm{C}$ as a multi-stage actor in its respective value chain 


\section{Finnish Knowledge-Intensive Business Services in China}

Sen Bao and Marja Toivonen

On the other hand, there were several indications of courage in entering Chinese markets. One case company is a born global and, for another, the Chinese market is their first foreign market. Deviating from earlier studies, not one of our companies had followed a domestic or other Western client to these markets. Here, the novelty of the expert areas may be one reason. Due to the small size of domestic markets, there is no one or very few clients with whom to internationalize. China is also a pioneering country in some areas - thus, the most dynamic demand can be found there. The ecocity case is an example of this phenomenon. In this case, the activities in China also promoted the company to win projects in the domestic markets.

Our study also highlights some specific issues that are important to take into account when entering Chinese markets. Irrespective of the form of international activities and the path followed, the role of local partners turned out to be central. The partners not only function as business references, but they may also provide additional resources and open doors to broader networks. A skilful combination of Western and Chinese resources is a success factor. The "foreign face" increases the credibility of the project, but local representatives are needed to secure smooth solutions in business practice. The price issue favours carrying out the most demanding expert tasks with a Western workforce and others with local resources.

As regards the value chains, we found that all companies in our study had established a role that reflects a desire to move away from a narrow position. One company is a service integrator, meaning that it coordinates the activities of upstream suppliers to provide broad solutions to the downstream clients. Our study indicates that this role requires profound knowledge, rich local experience, and abundant resources, including a good financial situation. Thus, this position is maybe not as easily adopted as earlier KIBS studies have suggested. There are also reasonable alternatives for this most demanding role: the roles of a concept designer and a multi-stage actor. A concept designer has much influence at the beginning of a project when potential demand is mapped. A multi-stage actor has flexibility as strength: various types of services can be offered according to the demand and the capacity of the provider. This opportunity is particularly important in emerging industries, as illustrated by our 3D solutions case.

A more general managerial implication of our study is open-mindedness in learning the characteristics of the Chinese business culture. Both the exaggeration of differences between Western and Eastern cultures and an over-assimilation of them are identifiable in earlier studies. The latter problem is visible in the analyses that evaluate the development in China similar to the Western development, just a couple of decades later. A similar perspective has been applied, for instance, when interpreting the current development stage of services. It is true that a long tradition in China has preferred goods over services, but now the situation is changing and the change may take place very rapidly in some respects. Our study shows examples regarding both topics and practices. Knowledge-intensive services linked to sustainability issues are a very modern approach, which China is now adopting. Value-based pricing is a business practice that is gaining a foothold in Western companies, and our small sample revealed it as a realistic alternative in China as well.

Because our study was based on a few cases in one country, more extensive studies are needed to generalize the results. Both the entry of Western KIBS to China and their positioning in the value chains there deserve further attention. In addition, it would be interesting to deepen our understanding about the KIBS market in China, including its similarities and differences compared to Western countries. Finally, our cases exemplify different value dimensions in the Chinese context: i) customer value (i.e., the balance between benefits and sacrifices); ii) provider value (i.e., paybacks and brand value); and iii) relationship value (i.e., trust, commitment, and loyalty). The interrelationships of these dimensions are an important area for further research. 


\section{Finnish Knowledge-Intensive Business Services in China}

Sen Bao and Marja Toivonen

\section{About the Authors}

Sen Bao is PhD candidate in the School of Science at Aalto University in Helsinki, Finland, where he also holds a Master's degree in Service Management and Engineering. He also works as Research Scientist in Business Ecosystems Development at VTT Technical Research Centre of Finland. He has over 4 years' working experience in service industries, half of it in the ICT sector. Currently, his research interests focus on service business development and internationalization of services. He is carrying out a research project on the service activities of Finnish manufacturers and technological knowledge-intensive business services (KIBS) in China.

Marja Toivonen is Research Professor at VTT Technical Research Centre of Finland, her specialty being service innovation and service business models. She is also Adjunct Professor at Aalto University in Helsinki, Finland. Marja has written several articles on service-related topics and been an invited speaker in many international conferences focusing on these topics. She is a council member of the European Association for Research on Services (RESER), and she is a member of the European Union's 2013-2014 High-Level Expert Group on Business Services.

\section{References}

Allee, V. (Ed.). 2003. The Future of Knowledge - Increasing Prosperity Through Value Networks. Burlington, MA: ButterworthHeinemann.

Brown, L. (Ed.). 1997. Competitive Marketing Strategy. Melbourne: Nelson.

Bryman, A. \& Bell, E. (Eds.). 2011. Business Research Methods. New York, NY: Oxford University Press.

Chesbrough, H. \& Rosenbloom, R. S. 2002. The Role of the Business Model in Capturing Value from Innovation: Evidence from Xerox Corporation's Technology Spin-off Companies. Industrial and Corporate Change, 11(3): 529-555. http://dx.doi.org/10.1093/icc/11.3.529

Chetty, S. \& Campbell-Hunt, C. 2004. A Strategic Approach to Internationalization: A Traditional Versus a "Born-Global" Approach. Journal of International Marketing, 12(1): 57-81. http://dx.doi.org/10.1509/jimk.12.1.57.25651

Contractor, F. J., Kundu, S. K., \& Hsu, C. 2003. A Three-Stage Theory of International Expansion: The Link between Multinationality and Performance. Journal of International Business Studies, 34(1): 5-18. http://dx.doi.org/10.1057/palgrave.jibs.8400003
Holmström, J., Louhiluoto, P., Vasara, A., \& Hoover, W.E. 2001. The Other End of the Supply Chain. Supply Chain Forum - An International Journal, 2(1): 22-25.

Horvath, L. 2001. Insight from Industry Collaboration: The Key to Value Creation in Supply Chain Management. Supply Chain Management - An International Journal, 6(5): 205-207. http://dx.doi.org/10.1108/EUM0000000006039

Howells, J. and Roberts, J. 2000. Global Knowledge Systems in a Service Economy. In Andersen, B., Howells, J., Hull, B., Miles, I. and Roberts, J. (Eds.), Knowledge and Innovation in the New Service Economy: 248-266. Cheltenham and Northampton: Edward Elgar.

Javalgi, R. G., Martin, C. L., \& Todd, P. R. 2004. The Export of EServices in the Age of Technology Transformation: Challenges and Implications for International Service Providers. Journal of Services Marketing, 18(7): 560-573.

http://dx.doi.org/10.1108/08876040410561884

Kaplinsky, R. 2004. Spreading the Gains from Globalization: What Can Be Learned from Value-Chain Analysis? Problems of Economic Transition, 47(2): 74-115.

Léo, P. \& Philippe, J. 2001. Internationalisation of Service Activities in the Haute-Gronne. The Service Industries Journal, 21(1): 63-80. http://dx.doi.org/10.1080/714005004

Lusch, R., Vargo, S., \& Tanniru, M. 2010. Service, Value Networks and Learning. Journal of the Academy of Marketing Science, 38: 19-31. http://dx.doi.org/10.1007/s11747-008-0131-z

Magretta, J. 2002. Why Business Models Matter. Harvard Business Review, 80(5): 86-92.

Majkgård, A. \& Sharma, D. D. 1998. Client-Following and MarketSeeking Strategies in the Internationalization of Service Firms. Journal of Business-to-Business Marketing, 4(3): 1-41. http://dx.doi.org/10.1300/J033v04n03_01

Miles, I. 2005. Knowledge Intensive Business Services: Prospects and Policies. Foresight, 7(6): 39-63. http://dx.doi.org/10.1108/14636680510630939

Miozzo, M. \& Miles, I. 2003. Introduction. In Miozzo, M. and Miles, I. (Eds.), Internationalization, Technology and Services: 1-11. Cheltenham and Northampton: Edward Elgar.

Morris, M., Schindehutte, M., \& Allen, J. 2005. The Entrepreneur's Business Model: Toward a Unified Perspective. Journal of Business Research, 58(6): 726-735. http://dx.doi.org/10.1016/j.jbusres.2003.11.001

O'Farrell, P. N., Wood, P. A., \& Zheng, J. 1998. Regional Influences on Foreign Market Development by Business Service Companies: Elements of a Strategic Context Explanation. Regional Studies, 32(1): 31-48.

http://dx.doi.org/10.1080/00343409850123602

Porter, M. 1985. Competitive Advantage. New York, NY: Free Press.

Qi, Y.S. \& Guan, P.L. 2009. Study on the Brain Drain Crisis Management Mechanism of Knowledge-intensive Business Services. Service Systems and Service Management, 8(10): 489-492. http://dx.doi.org/10.1109/ICSSSM.2009.5174933

Rappa, M. 2001. Managing the Digital Enterprise - Business Models on the Web. April 1, 2014:

http://ecommerce.ncsu.edu/business_models.html 


\section{Finnish Knowledge-Intensive Business Services in China}

\section{Sen Bao and Marja Toivonen}

Roberts, J. 1998. Multinational Business Service Firms: The Development of Multinational Organisational Structures in the UK Business Services Sector. Aldershot: Ashgate.

Shafer, S. M., Smith, H. J., \& Linder, J. C. 2005. The Power of Business Models. Business Horizons, 48(3): 199-207.

http://dx.doi.org/10.1016/j.bushor.2004.10.014

Sharma D.D. \& Johanson J. 1987. Technical Consultancy in Internationalization. International Marketing Review, 4(4): 20-29. http://dx.doi.org/10.1108/eb008339

Shyu, J.Z., Chen, C.J., \& Yang, C.H. 2007. A Business Model for Knowledge-Based Service Enterprises in China: The Case Study of Kunshan. Proceedings of International Conference on Chinese Enterprises Research:265-282.

Tapscott, D., Ticoll, D., \& Lowy, A. 2000. Digital Capital: Harnessing the Power of Business Webs. London: Nicholas Brealey Publishing.
Toivonen, M. 2002. Internationalization of Knowledge-Intensive Business Services in a Small European Country: Experiences from Finland. In Miozzo, M.; Miles, I. (Eds.), Internationalization, Technology and Services: 206-226. Cheltemham: Edward Elgar Publishing Ltd.

Wei, J. \& Wang, T. 2005. Comparison of EU Knowledge-Intensive Business Services with China Ones. Chinese Journal of Management, 2(3): 312-316.

Windrum, P. 2002. The Role of Knowledge-Intensive Business Services (KIBS) in e-Commerce. In Pyka, A. and Kuppers, G. (Eds.), Innovation Networks - Theory and Practice: 108-133. Cheltenham and Northampton: Edward Elgar.

Zhou, J., Tang, C., \& Xiong, W. 2005. Interactive Relationship between KIBS and Knowledge Environment. International Journal of Technology Management, 32(3/4): 288-301. http://dx.doi.org/10.1504/IJTM.2005.007335

Citation: Bao, S. \& Toivonen, M. 2014. Finnish Knowledge-Intensive Business Services in China: Market Entry and Position in the Value Chain. Technology Innovation Management Review, 4(4): 43-52. http://timreview.ca/article/784

Keywords: knowledge-intensive business services, KIBS, internationalization of services, Western companies in China 